\title{
Modernization of Information Technologies Studies at University Level
}

\author{
Juozas ADOMAVIČIUS, Eduardas BAREIŠA, Vitalija KERŠIENĖ, \\ Vitolis SEKLIUCKIS \\ Kaunas University of Technology \\ Studentu 50, 51368 Kaunas, Lithuania \\ e-mail:juozas@pit.ktu.lt,edas@soften.ktu.lt,vitker@pit.ktu.lt,vitolis@pit.ktu.lt
}

Received: December 2003

\begin{abstract}
The article examines update of modules of general IT (Informatics) studies under changes in secondary school programs. It is proposed to create distance-learning courses and use "tools set" principles. It will allow broadening the choice of study subjects and will create possibility for students from different faculties to choose the subjects and realization tools that better meet their needs and fields of studies. The developed materials will be available to all students and staff willing to improve IT skills through distance learning. Tasks and knowledge control will be unified in the whole University. The materials of updated Informatics courses will be presented in a virtual learning environment WebCT, including self-control tasks and tests. This will also be very useful for correspondence students.
\end{abstract}

Key words: e-learning, information technologies, informatics.

In this paper the modernization aspects of modules of general information technologies (IT) studies are examined according to changes in a secondary school program. It is proposed to create modules of distance studies and to give an opportunity for the students of various faculties to choose the subjects and implementation tools that better suit their needs and fields of studies. Updated discipline modules will be presented in a WebCT virtual learning environment.

\section{Problems of IT Teaching at School}

Volatile situation in IT teaching at basic and secondary school has inevitable impact on a content and methodology of further teaching at university. A first year student who just entered the university should be familiar with the terms of Informatics and with the most frequently used information technologies (Blonskis and Dagiené, 2003). This issue follows after examining already approved secondary school educational program. On the other hand, facing the level of real knowledge of first year students, it is hard to expect that secondary school graduates will be able to perform one of the first tasks appointed in a program - to be able to apply IT knowledge and concepts according to 
social changes. Furthermore, in order to model the mentioned processes, proper studies namely in universities and higher schools should be provided.

It is useful to examine results of a popular pupils' IT contest organized at Kaunas University of Technology (KTU) for several years. Competition tasks are compiled according to requirements of a general IT educational program of a secondary school. The major focus is on the use of IT in everyday life. In 2002, 100 pupils from 41 secondary schools participated at this event, in 2003 - 132 pupils from 61 secondary schools. In 2002 the average of all possible points earned by participants was $20 \%$, in $2003-28 \%$. Fig. 1 shows that even the best pupils coming from various schools face difficulties in application of IT knowledge.

Results of the most advanced pupils (see Fig. 2) are slightly more optimistic. However, in 2002 average score of half of the participants got only $8 \%$ of all possible points. In 2003 year competition this rate raised up to $15,8 \%$.

Despite the fact that some tasks of the educational program are hardly achieved, the knowledge level of the undergraduates grows. Fig. 1 shows that more and more pupils are able to reach a limit of $20 \%$ points.

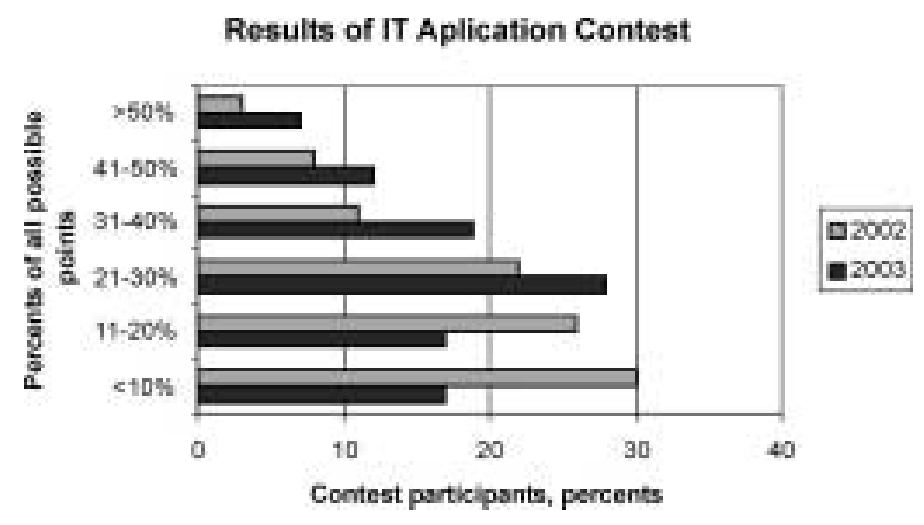

Fig. 1. Comparison of contest results.

Best Pupils' Results

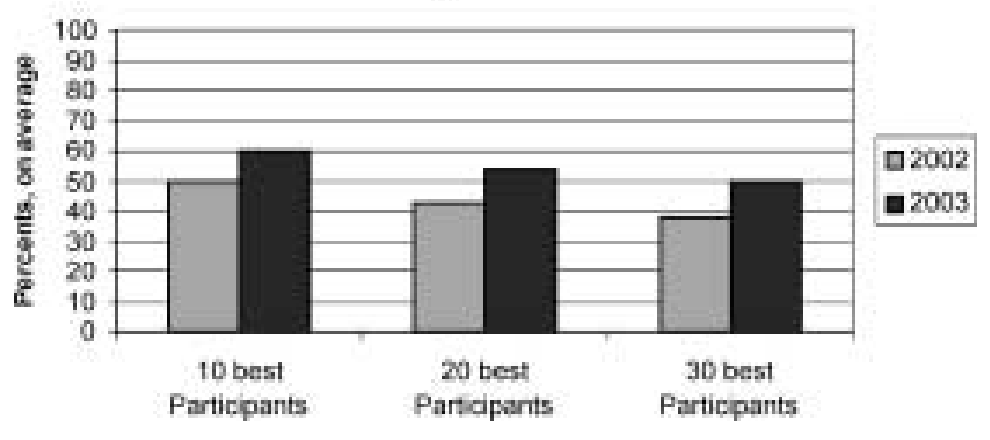

Fig. 2. Best pupils' results. 
Growing differentiation of knowledge is very threatening. However, it is already predetermined. According to the "Information Technologies" educational program approved by order of Minister of Education and Science of Lithuania (No. 1465, dated 21st of August, 2002), in the extended course a pupil studying in every profile can choose only one module from the three offered for the course:

- databases;

- programming;

- hypertext and multimedia.

In authors' opinion, the knowledge of the first and third modules is essential for all students. The second module is not so important for studying traditional programming. It is much more important for development of algorithmization, logical thinking skills and also use of those skills in specific areas. It seems that it is too early to apply a specialized teaching in a secondary school, because, in that way, part of students at university level will have to study those subjects once again.

Studies at university level differ from the ones at secondary school, as university students have to choose a particular field of study. Therefore, practical classes must be highly oriented towards this specific field of studies. Theory lectures should help student to make a choice among many existing IT, extend his knowledge acquired at school and apply it in personal studies.

According to the mentioned above, authors consider that studies of general informatics at university level must be partially specialized. Theory, as before, can be lectured according to general educational program, but laboratory and individual works must be specialized according to the faculty field of study.

\section{Current Studies of IT at University Level}

Students are studying IT at all universities in Lithuania. Table 1 shows an extent of IT disciplines, lectured at economical (management) field of studies. As it can be seen from Table 1, the extent of provided studies is bigger at technical universities. Generally, IT studies in all universities are getting similar throughout the last years (Valavičius, 2002). According to the profile of the university or field of studies the studies of informatics consist of following subjects:

- IT development, hardware and software review;

- operating systems;

- word processing and graphic objects;

- spreadsheets;

- preparation of presentations;

- internet services;

- numerical methods and algorithms;

- usage of mathematical packages;

- databases; 
Table 1

Extent of studies of IT at different Universities in Lithuania

\begin{tabular}{|c|c|c|c|c|c|c|c|}
\hline \multirow{2}{*}{$\begin{array}{l}\text { Nr. } \\
1\end{array}$} & \multirow{2}{*}{$\begin{array}{l}\text { University } \\
\text { VDU }\end{array}$} & \multirow{2}{*}{$\begin{array}{l}\text { Discipline } \\
\text { Informatics }\end{array}$} & \multirow{2}{*}{$\begin{array}{c}\begin{array}{c}\text { Extent } \\
\text { (credits) }\end{array} \\
4.5\end{array}$} & \multicolumn{3}{|c|}{$\begin{array}{c}\text { Hours per week } \\
\text { (lect., lab., practice) }\end{array}$} & \multirow{2}{*}{$\begin{array}{c}\text { Semester } \\
-\end{array}$} \\
\hline & & & & & - & & \\
\hline \multirow[t]{2}{*}{2} & \multirow[t]{2}{*}{ VGTU } & Information technologies 1 & 4 & 2 & 3 & 0 & 1 \\
\hline & & Information technologies 2 & 4 & 2 & 3 & 0 & 2 \\
\hline \multirow[t]{2}{*}{3} & \multirow[t]{2}{*}{ VU } & \multirow[t]{2}{*}{ Economical informatics } & 2 & 0 & 1 & 1 & 1 \\
\hline & & & 2 & 0 & 1 & 0 & 3 \\
\hline \multirow[t]{3}{*}{4} & \multirow[t]{3}{*}{ VU KHF } & Informatics & 4 & 2 & 2 & 2 & 1 \\
\hline & & Information technologies & 4 & 2 & 4 & 0 & 4 \\
\hline & & Communication & 2 & 1 & 0 & 2 & 7 \\
\hline \multirow[t]{2}{*}{5} & \multirow[t]{2}{*}{ KTU } & Informatics 1 & 4 & 2 & 3 & 0 & 1 \\
\hline & & Informatics 3 & 4 & 2 & 3 & 0 & 2 \\
\hline
\end{tabular}

- hypertext;

- multimedia

- programming in the specialized application packages (Matlab, Mathcad, AutoCAD, etc.).

The last four subjects are usually studied in theoretical, fundamental level, because of the lack of credits.

Lithuanian students who complete IT educational programs have skills and knowledge corresponding (or nearly corresponding) to standards of international certification, for example ECDL.

A research of students' knowledge on IT carried by the authors' at Kaunas University of Technology (KTU) shows that average mark of students' at the end of the first semester is 7 (enough) or higher. Number of students with high evaluation marks increases. That is shown in Fig. 3, where a level of IT knowledge of first year students in the faculty of Electrical Engineering and Control Systems is shown. It is evident (see Fig. 4), that

Evaluations of Students' IT Knowledge in 2002 and beginning of 2003

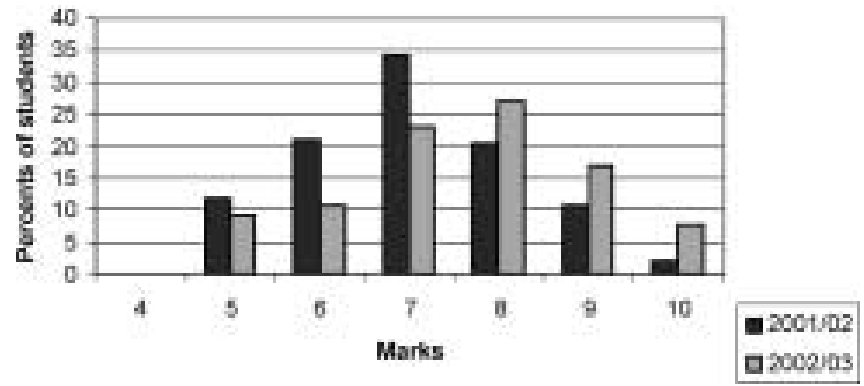

Fig. 3. Evaluation of students' IT knowledge. 
Evaluations of Students" IT Knowledge

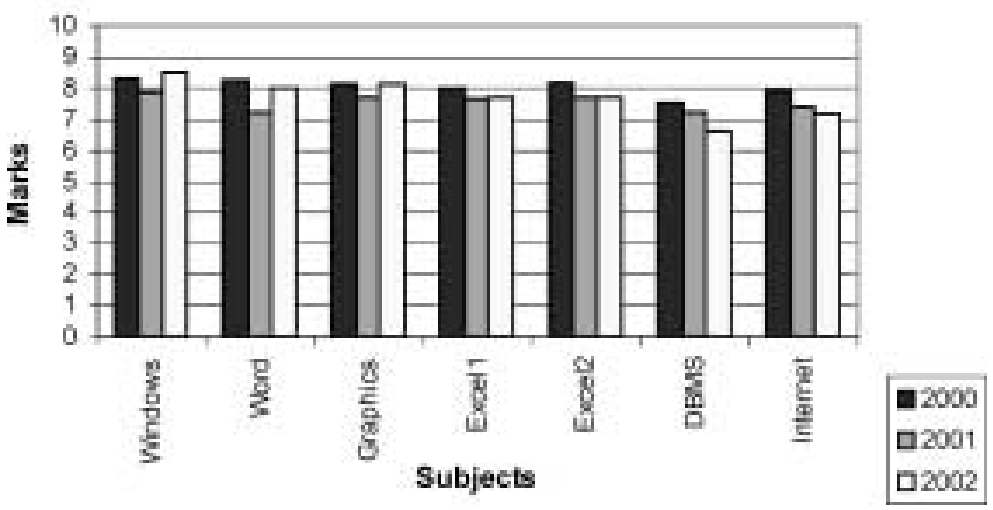

Fig. 4. Evaluation of students' IT knowledge according to the module subjects.

the knowledge of Windows, Word Processing and graphical applications is improving, because the materials of these subjects partially repeat a school course.

That is why the program of these subjects should be updated at the university level. At KTU this is done by updating the studies program of the module "Informatics 1" (analysed in the following sections). Unfortunately the same cannot be told about the remaining subjects.

According to Fig. 4, students' marks there the best in 2000. There can be some reasons for that:

- the knowledge of newly entered students deteriorate;

- students devote less time and efforts for informatics studies;

- knowledge requirements are growing at KTU.

In general, the knowledge of the students decline in the fields, those are not obligatory in the schools (e.g., databases). In some subjects (e.g., Word processing) requirements are growing at KTU, because the knowledge of students is improving.

Renewed educational program of informatics for secondary schools is oriented to the base level of ECDL. Therefore, universities have to train students with higher IT knowledge level, necessary not only to use IT, but also to create their own products in specific study areas. Such qualified users can be classified by the following knowledge and abilities (Sekliuckis et al., 2003):

- Knowledge of basic principles of algorithmization, functional and object programming, application of this knowledge;

- Ability to design structure of products, necessary for their activity and implement it using common tools of program packages. Examples of such products are reports, books, websites, databases, activity parameters (financial or economical) calculation, programs of estimation and analysis, etc.;

- Ability to choose appropriate IT or integrated IT set in order to solve their tasks;

- Ability to install and control computer security tools as well as own products. 
The mentioned facts indicate that university level IT study programs must be updated. Also it must be taken into account that students enter the universities with different level of knowledge. All students should reach at least ECDL level after completion of first year studies. On this base is possible to make their studies more proper by focusing to IT objects design, i.e., creation of their structure and integrated usage of particular environment tools. For organising such university level IT studies it is purposeful to use techniques based on principles of structural design. In this case, "to design" tools to create the IT object's structure, choose most effective implementation tools, procedures and means (later in abbreviation - implementation means).

\section{Use of Structural Approach for IT Studies at Universities}

Means and methods of IT studies are mainly oriented to analysis of IT tools. Usually it is shown how to use different tools while creating separate parts of IT objects. For users prepared in such a manner it is difficult (or even impossible) to create an effective IT object. In fact, most of them do not know how to use known tools to reach their targets - which tools and in what sequence could be used for the best effect. Therefore, one of the essential objectives towards the modernization of IT studies at universities should be the development of the ability to choose the most effective IT tools for specific purposes. Teaching materials must be presented in appropriate form with possibilities to study different topics according to the needs of students. All materials (lectures, laboratory works, self-control tasks, etc.) must be revised and presented in very structured form.

On the other hand, students have IT basics that they've got at school. They need rise to higher level - not only apply separate IT but professionally use set of them to create a new IT object. In order to do that they must know some principles of design and should be able to distinguish structural parts of IT object, analyse them, create an effective structure and choose implementation tools.

For example, students usually have no problems to create some simple IT object (MS Word document) with tables and graphics. Difficulties appear while fulfilling the task when only the description or the sketch of required document is presented, especially if the document is quite big and consists of many different structural parts. In this case the user must identify typical structural parts of the document, set their parameters, choose implementation means, etc.

In our opinion, while teaching IT at universities, major attention should be paid to studies by designing (realising different tasks) with necessity to create object's structure and to choose implementation tools. We recommend using basic principles of structural design. It is based on use of alternative choices of object's structure. Every object to be designed can be realised using several structural options. Respectively, every structural variant can consist of some typical elements. Every typical element can be implemented using different tools. In this case aim of designing is to create an effective structure from alternative object variants using alternative implementations of typical elements.

It is recommended to use principles of structural design for IT objects with the following features: 
- Possibility to identify and describe typical elements - object can be implemented using those elements;

- Set of standard implementation tools for every typical element;

- Alternative object implementation possibilities with alternativeness in typical elements and in implementation tools.

Widely used IT objects (databases, word documents, spreadsheets, etc.) contain similar features.

Application of structural designing principles for IT studies means that studies should be started not from analysis of isolated implementation tools, but from analysis of IT object structure. Typical elements should be identified, described and related with presumptive implementation tools. Usually there can be different IT object structures, i.e., structural variants.

For implementation of structural variant, the designing rules (later in abbreviation - rules) should be defined. As it was mentioned before, a particular structural variant can contain several variants of realization, i.e., several sets of rules. These rules can be described as an algorithm.

From structural point of view IT object can be formally described using following relationships:

$$
\begin{aligned}
& \forall i: A^{i}=\left(R, S^{i}, T^{i}\right) ; \quad S^{i}=\bigcup_{j} E_{j}^{i} ; \\
& \forall j: E_{j}^{i} \rightarrow\left(P_{j}^{1}, P_{j}^{2}, \ldots, P_{j}^{m}\right) ; \\
& \quad i=1,2, \ldots, I ; j=1,2, \ldots, J^{i} ;
\end{aligned}
$$

where:

$i$ - number of structural variant,

$A^{i}$ - description of IT object ( $i$ - variant),

$R$ - description of functions to be realised and appropriate initial data to be prepared,

$S^{i}$ - description of structural variant's as a set of distinguished typical elements,

$T^{i}$ - description of rules for the design of structural variant,

$E_{j}^{i}$ - set of possible implementation tools $P_{j}^{k}$ realising typical elements.

Databases (DB) developed in MS Access environment can be an IT object example. Individual parts (see description above) of formalized description can be interpreted as follows: $R$ will constitute of initial data for DB application, i.e., schemes of DB tables. Besides, requirements for formats and contents of the documents to be saved in DB, i.e., DB requirements for forms, reports and queries, are integrated into $R$. Set of distinguished typical elements $E_{j}^{i}$ consists of DB main objects: tables, forms, queries, reports. If a particular $E_{j}^{i}$ is a DB form, thus three possible implementation tools will match it: wizard, design and properties. It is advisable to present an algorithm for every realization type $P_{j}^{k}$.

Students' IT knowledge should be evaluated not only by IT assessment tests but also by assessment tasks describing students' ability to perform an individual work including IT object structure design and complete realization. 
General technique of IT object's structural design, applied in general process of IT studies, can be described as follows:

1) to distinguish IT object structural variants;

2) to form typical elements set for every structural variant;

3) to choose implementation tools set for every typical element;

4) to choose the most effective typical element's realization;

5) to choose the most effective structural variant.

Described principles are used while creating structure of study materials. It is discussed in following sections.

\section{Proposed Structure of Teaching Materials}

As it was stated before, according to the changes in the educational programs of secondary schools, not basic knowledge on e-work, but their principles must be lectured at universities aiming to use the acquired knowledge in the further process of studies. It is necessary to generalize IT application facilities for studies and future field of activities. Besides, along with the well-known but relatively expensive products of Microsoft and other companies, so-called open-source software is distributed, Internet technologies are developed and new graphics and animation programs are developed. Thus, students of different study programs as well as other members of developing knowledge society have to be familiar with their potential applications. A necessity for renewal of content of Informatics modules and its teaching methodology as well as application of experience of other universities in the world (Skills ..., 2003; Zaitseva et al., 2003) emerges. Therefore, authors propose to eliminate hard-and-fast introduction of isolated tools, to update curriculum and to give a chance for students of different faculties to choose subjects and tools best corresponding to their field of studies. Certainly, a core of the general module content must remain. Therefore, it is proposed to implement a "set of elective tools" principle.

At KTU three general modules of Informatics in bachelor program ("Informatics 1" (4 credits) - in the first semester, "Informatics 2" ( 2 credits) or "Informatics 3" (4 credits) - in the second semester) are lectured almost for all students (except students from Informatics and Fundamental sciences faculties). Hence, almost 4000 first year students of KTU will use a newly prepared material.

Since many extra-mural students (about 1500) study the mentioned modules, the distance-learning tools will significantly ease the course presentation and learning. The material will also be useful for full-time and part-time students. It is easier to update a distance course material than a traditional course-book, and that is very important for Informatics studies.

The subjects of the adapted module Informatics 1 for distance learning directly depend on the choice of the faculty. The module consists of 4 parts including 14 different program packages that will be used in practice classes. The packages are chosen according to the field of studies, matching experts' suggestions and needs of the faculties. In total, it is 
Table 2

Faculty choices of Informatics alternatives for the first semester

\begin{tabular}{|c|c|c|}
\hline Informatics 1 & $\begin{array}{c}\text { Lecture } \\
\text { hours }\end{array}$ & $\begin{array}{c}\text { Max } \\
\text { lab. hours }\end{array}$ \\
\hline E-workplace, tools & 6 & 0 \\
\hline Windows & 0 & 4 \\
\hline Unix & 0 & 0 \\
\hline Linux & 0 & 0 \\
\hline MS Internet Explorer & 0 & 6 \\
\hline OpenOffice Mozilla & 0 & 2 \\
\hline Netscape Navigator & 0 & 0 \\
\hline Computer safety & 2 & 0 \\
\hline Word processing systems & 2 & 0 \\
\hline MS Word & 4 & 10 \\
\hline OpenOffice Writer & 2 & 4 \\
\hline PageMaker & 0 & 0 \\
\hline WordPerfect & 0 & 0 \\
\hline FrontPage & 4 & 16 \\
\hline Multimedia products & 2 & 0 \\
\hline MS Drawing, WordArt & 2 & 2 \\
\hline CorelDraw & 2 & 12 \\
\hline Photoshop & 2 & 8 \\
\hline MS Visio & 2 & 6 \\
\hline MS PowerPoint & 2 & 4 \\
\hline OpenOffice Impress & 0 & 0 \\
\hline Flash & 2 & 12 \\
\hline Spreadsheets, databases & 2 & 0 \\
\hline MS Excel & 2 & 10 \\
\hline OpenOffice Calc & 0 & 0 \\
\hline MS Access & 4 & 12 \\
\hline OpenOffice DB manager & 0 & 0 \\
\hline Total: & 42 & 108 \\
\hline
\end{tabular}

planed to prepare a distance learning tools including 42 hours of lectures and 108 hours of practice (Table 2). Modules Informatics 2 and Informatics 3 are related to Informatics 1. As content of the latter module will gain new quality (laboratory and individual work will be specialized according to the chosen field of study), themes of the second semester must complement with the needs of the faculties and the ones of the module Informatics 1 . Such measures will retain a continuation and succession of the studies. Table 3 shows, that students in the second semester have to choose section of algorithmization and one of 4 programming environments, dedicated to implement practical tasks.

Content of every part is presented separately. Content of the part "Word processing system" of the module "Informatics 1" is presented in Table 4. Content analysis shows that several subjects, i.e., "MS Word basics" are eliminated from KTU study program while principles of complex Word processing are studied. 
Table 3

Faculty choices of Informatics alternatives for the second semester

\begin{tabular}{|c|c|c|c|}
\hline & Informatics 2 (3) & Lecture hours & Max lab. hours \\
\hline \multirow{3}{*}{ Progr. 1} & Algorithmization Programming environments & 8 & \\
\hline & Interpreter programs (VBScript) & 4 & 20 \\
\hline & Web design by integrating VBScript into HTML & 4 & 12 \\
\hline Progr. 2 & Problem solving in Mathcad environment & 8 & 32 \\
\hline Progr. 3 & Problem solving in Matlab environment & 8 & 32 \\
\hline \multirow[t]{2}{*}{ Progr. 4} & Programming in Visual Basic environment & 8 & 32 \\
\hline & Total: & 40 & 128 \\
\hline
\end{tabular}

Table 4

Word processing systems

\begin{tabular}{|c|c|c|c|c|}
\hline No. of Topic & Lecture Topics & Hours & Laboratory & Hours \\
\hline 1. & $\begin{array}{l}\text { Overview of Word } \\
\text { processing systems }\end{array}$ & $2(\mathrm{VL})$ & & \\
\hline \multirow[t]{3}{*}{2.} & $\begin{array}{l}\text { Word processing tools } \\
\text { in MS Word environ- } \\
\text { ment }\end{array}$ & 4 & $\begin{array}{l}\text { Tools for preparation of complex documents } \\
\text { Documents of a special purpose (forms, se- } \\
\text { rial documents) }\end{array}$ & 2 \\
\hline & & & $\begin{array}{l}\text { Automation of repetitive functions (macro- } \\
\text { commands, text spelling, etc.) }\end{array}$ & 4 \\
\hline & & & Work place adaptation to user's needs & 2 \\
\hline \multirow[t]{2}{*}{3.} & Word processing tools & & Means of complex document preparation & 2 \\
\hline & $\begin{array}{l}\text { in Open Office Writer } \\
\text { environment }\end{array}$ & 2 & $\begin{array}{l}\text { Documents of a special pupose (forms, serial } \\
\text { documents) }\end{array}$ & 2 \\
\hline \multirow[t]{4}{*}{4.} & $\begin{array}{l}\text { Word processing tools } \\
\text { using MS FrontPage }\end{array}$ & 4 & $\begin{array}{l}\text { MS FrontPage environment. Possibilities for } \\
\text { text edditing, insertion of graphic elements }\end{array}$ & 4 \\
\hline & & & Table usage in websites, purpose of frames & 4 \\
\hline & & & References, website structure & 2 \\
\hline & & & $\begin{array}{l}\text { Website interactive elements (configura- } \\
\text { tions, components). Website presentation }\end{array}$ & 6 \\
\hline Total of pro & ed lectures, in hours: & 12 & Total of proposed laboratory, in hours: & 30 \\
\hline
\end{tabular}

Remark. Slides are prepared for 4 lectures (one of them - a video lecture (VL)), self-control and assessment tests, and descriptions of 26 hours laboratory works: short theoretical part, standard task, and examples of a control task in virtual environment.

Courses of Informatics studies are supposed to be presented in a WebCT virtual learning environment, main lectures - through a video broadcasting system ViPS. For some themes, a specialized testing tool Test Tool will be used. Presentation of a course in virtual environment will improve quality of the material, as lecturers will be able to specialize in more specific areas. Similarly, tasks and knowledge monitoring will be unified in the whole university. For the lectures in any section MS Power Point presentations and commentaries, if needed, will be done. Total number of hours of prepared lecture material 
equals to $42+40=82$ hours. Besides that, the main lectures (not less than 8 hours per module) are prepared through ViPS. These are for correspondence students who will also have an opportunity to view slides of other lectures and to learn other discussed subjects.

\section{Material Delivery}

Students of all study types will find material of the studies in the same virtual system and will select only those themes, which are included in their faculty set of modules. Material, presented in the virtual environment, consists of lecture slides, material of laboratory works, communication tools, and self-control and assessment tests.

Total of material of laboratory works equals to $108+128=236$ hours. However, the students from different faculties will be provided with sets of different topics. Consequently, full-time students will organize their individual study programs under $48+48$ hours of laboratory works. The descriptions of all laboratory works will consist of a short theoretical part, practical task example, assessment task or test of laboratory work. Practical task will be a recommendation-type realization algorithm described using step-bystep style. References and the Internet sources will be recommended for every theme. An approximate time limit, which is necessary for learning and performing practical tasks, will be prescribed. $50 \%$ of all module material is completely new; another part is updated, supplemented and adapted to the virtual environment. As the individual study program of correspondence students for laboratory consists of only 24 hours, it was difficult to master information technologies at a required level. As soon as study material for a maximum desirable number of hours of chosen theme is completed, the students will have much more opportunities to acquire more knowledge of examined subjects.

\section{Communication Tools}

Students will interact with lecturers in auditorium, computer class or via e-mail. In discussions they could consult their lecturers as well as authors of different themes. The students of every faculty will use their own message board, where lecturers will provide a calendar of the major tasks. Students' assessment tables will also be designed and their analysis will be performed.

All material in virtual environment is presented in two levels. Dynamical part consisting of self-control and assessment tests, communication, information, results of the studies, exam schedule, etc. is saved in the WebCT environment. References for learning material also exist (see Fig. 5). All learning material consisting of slides of lectures, theoretical part of the laboratory, standard tasks, examples of control tasks, recommended self-study material is saved in a server of the department (see Fig. 6). However a student studying in the Web CT environment faces almost no differences as all the parts operate in a consecutive order. 


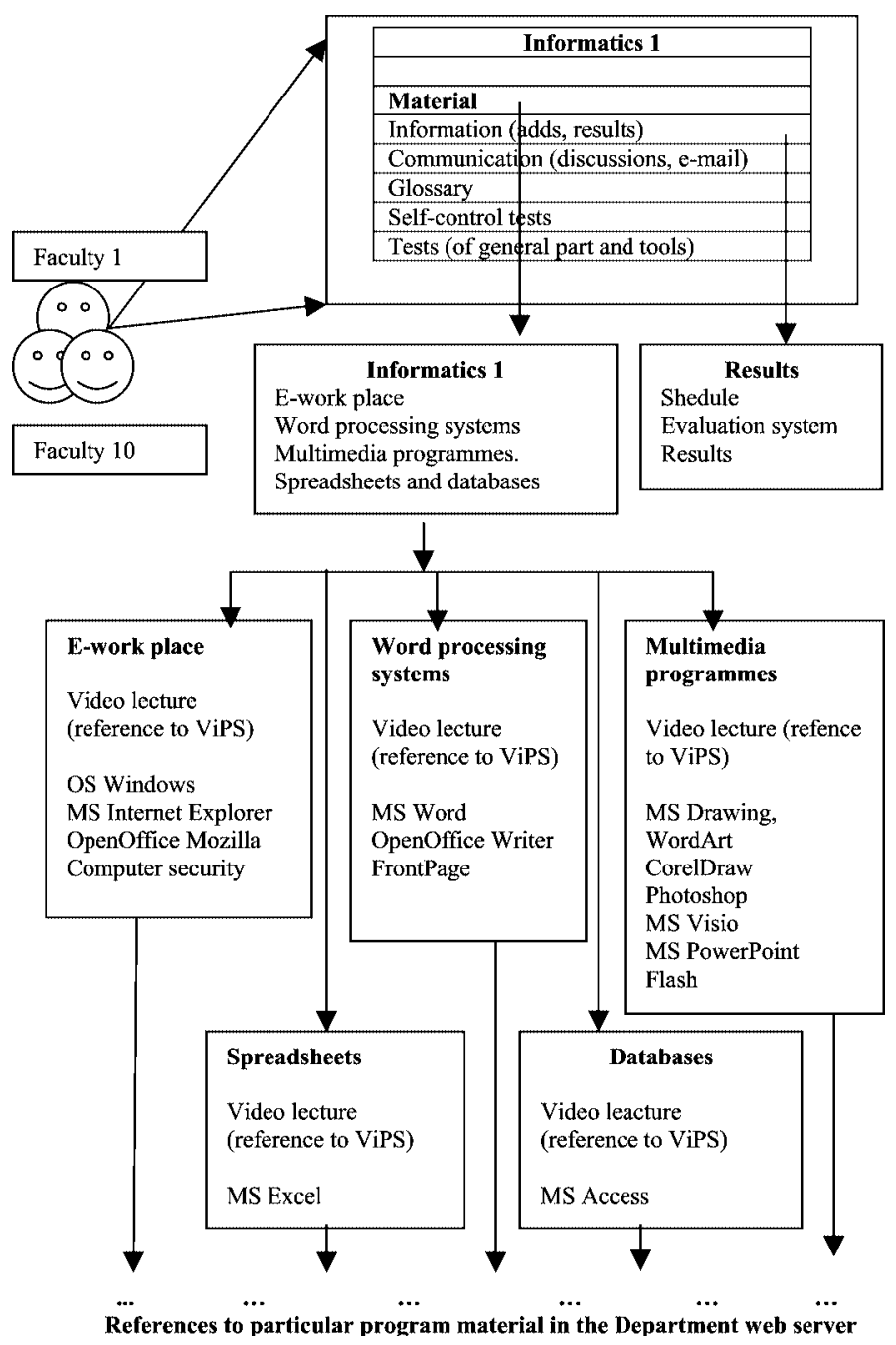

Fig. 5. Structure of a distance learning course "Informatcs 1".

\section{Conclusions}

1. The situation at secondary schools of Lithuania has changed. Pupils acquire basic IT knowledge (at the ECDL basic level). Therefore, abilities for proper learning and processes modelling must be further developed at the university level.

2. A number of pupils (about 20\%) who will not be able to master all the themes presented in a secondary school educational program is expected, therefore at universities such students will have to make odds of theirs knowledge even on their own. On the other hand, at university some optional secondary school topics will be lectured from a start. 


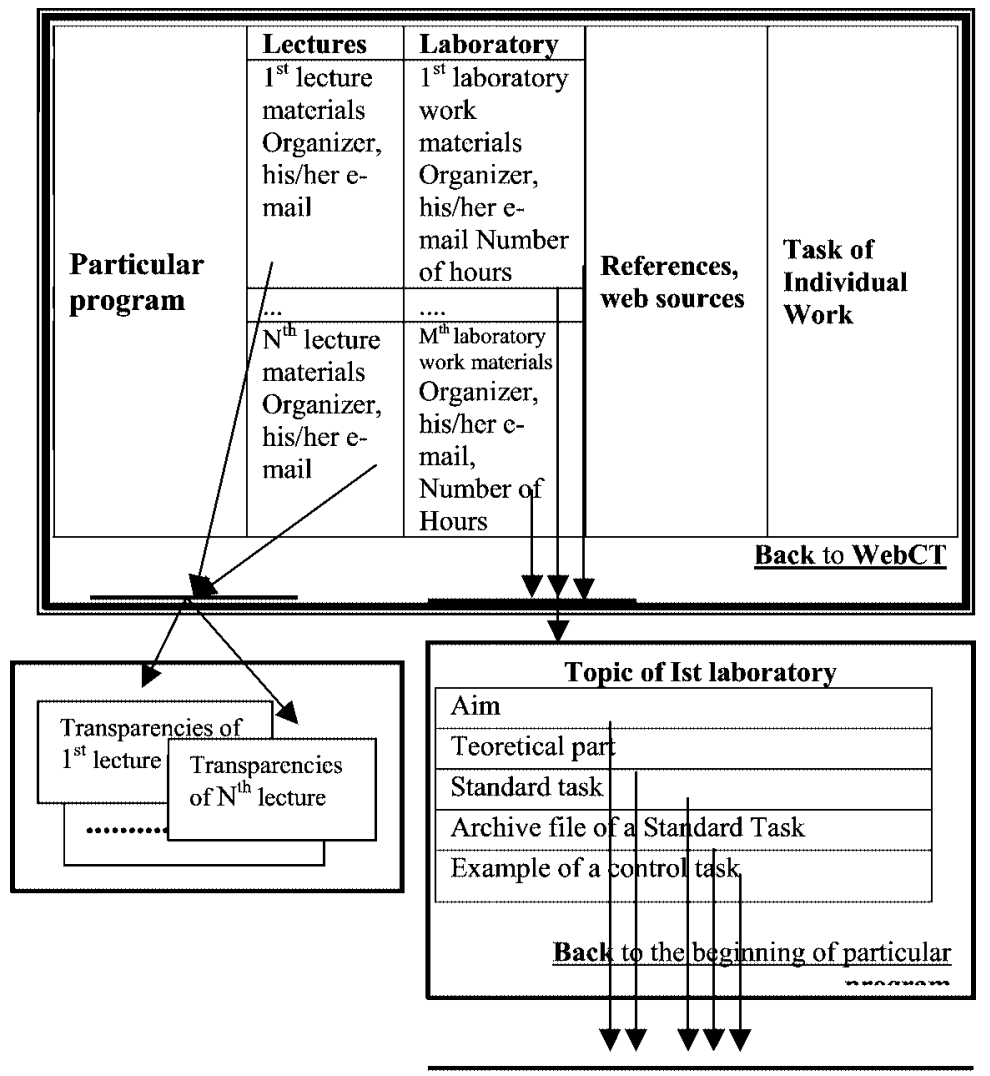

Files of description

Fig. 6. Structure of HTML file system of particular program material.

3. Structure of IT modules are similar in extent and content at different Lithuanian universities. The content must be updated and prepared for 'qualified' IT users.

4. For IT studies at university level it is advisable to apply technique, which is based on structural design principles.

5. Principle of set of alternatives and implementation tools is proposed for the university studies, i.e., lectures of IT problem-of-use-solution type while content of laboratory works corresponds to the needs of the faculty.

6. Set of alternatives and implementation tools avoids exceptions of any package and allows open-source program application.

7. Module presentation through a virtual environment allows better quality in material preparation, knowledge control unification and encourages students and lecturers to virtual communication. 


\section{References}

Blonskis, J., and V. Dagienė (2003). Programavimo pagrindų mokymo vidurinejje ir aukštojoje mokyklose lyginamoji analizè (in Lithuanian, The problems of teaching basic elements of programming in secondary and higher schools). Informacijos mokslai, 26, 23-28.

Niemi, E., and R. Karjalainen (2003). Information and communication technology as an innovation in educational institutions. In Technology Enhanced Learning in Digital Age, Proceedings of the International Conference. Technologija, Kaunas, pp. 16-21.

Sekliuckis, V., J. Adomavičius and G. Garšva (2003). Informaciniu technologiju icvaldymas struktūrinio projektavimo požiūriu (in Lithuanian, Use of structural design approach for IT mastering). Informacijos mokslai, 24, 68-73.

Skills for the Academic e-Workplace (2003). http: //ist. uwaterloo.ca/ campbell/saw/.

Valavičius, A. (2002). Informacinių technologijų dėstymo perspektyvos (in Lithuanian, Perspectives of teaching information technologies). In Informacinès technologijos 2002. Technologija, Kaunas, pp. 101-105.

WebCT, the World's Leading Provider of E-learning Solutions to Higher Education (2003). http: //www. webct.com/.

Zaitseva, L., J. Bule J. and U. Kuplis (2003). Advanced e-learning system development. In Advanced Learning Technologies and Applications, Procedings of the International Conference. Technologija, Kaunas, pp. 14-18. 
J. Adomavičius got a degree in computer science from Kaunas Politechnical Institute in 1970. In 1978 he obtained PhD degree and since then he has been working as associate professor at Software Engineering Department, Kaunas University of Technology, Lithuania. His main research interests include software engineering, e-learning and information technologies in education.

E. Bareiša obtained PhD degree from Kaunas Politechnical Institute in 1987. Currently he is in position of assoc. professor at Software Engineering Department, Kaunas University of Technology, Lithuania. His research interests include high-level synthesis and VLSI test generation.

V. Keršienė graduated from Kaunas Politechnical Institute in 1975 as computer science specialist. She is lecturer at Kaunas University of Technology Software Engineering Department. Hers research interests are information technologies in education, multimedia and developing of e-learning applications.

V. Sekliuckis received PhD degree from Kaunas Politechnical Institute in 1976. Currently he is in position of assoc. professor at Software Engineering Department, Kaunas University of Technology, Lithuania. His research interests include: advanced learning technologies, information systems, data security. 


\title{
Universitetiniu informacijos technologijų studiju modernizavimas
}

\author{
Juozas ADOMAVIČIUS, Eduardas BAREIŠA, Vitalija KERŠIENĖ, \\ Vitolis SEKLIUCKIS
}

Besikeičianti informaciniu technologijų (IT) mokymo vidurinèje mokykloje situacija neišvengiamai itakoja jụ tolesnių studiju universitete turini ir metodiką. Panagrinejus patvirtintas vidurinès mokyklos programas atrodo, kad abiturientai turetų būti ivaldę pagrindines informatikos sąvokas ir dažniausiai naudojamas IT. Tačiau nors mokinių žiniu lygis kyla, jis vis dar nepakankamas, ypač kai jas reikia taikyti konkretiems praktiniams uždaviniams spręsti. Tai patvirtina KTU Informatikos fakultete jau kelerius metus vykdoma moksleivių konkurso rezultatų analizė. Be to, didèja moksleivių žinių diferenciacija, nes išplèstiniame informatikos kurse mokinys turi pasirinkti vieną iš trijų modulių (duomenų bazès, programavimas, hipertekstas ir multimedija). Autorių nuomone ši specializacija yra pernelyg ankstyva, nes po to universitete tenka kartoti daliai studentų žinomus dalykus.

Universitetinès studijos skiriasi nuo mokyklinių, nes studentai pasirenka specifinę studiju krypti. Praktiniai darbai turi ją atitikti, o paskaitos planuotinos taip, kad padètų studentui suvokti, kurias IT pasirinkti ir pritaikyti sprendžiant savo srities uždavinius. Taigi, autorių nuomone, IT studijos turi būti dalinai specializuotos.

Pastaraisiais metais bendrosios IT studijos Lietuvos universitetuose savo turiniu supanašèjo. Gerai besimokantys studentai igyja žinias ir igūdžius, atitinkančius tarptautinius standartus, pvz., ECDL. Atnaujinta vidurinès mokyklos informatikos ugdymo programa taip pat orientuojama i bazini ECDL lygi. Taigi, universitetinès bendrosios informatikos studiju programos turi būti nuolat atnaujinamos. Jų tikslas - ugdyti studentus aukštesniu lygiu, kuris būtụ pakankamas naujiems produktams specifinėse studiju ir tolesnès veiklos srityse kurti. Kadangi bendras žinių lygis kyla, daugiau dèmesio galima skirti nauju IT objektu projektavimui, t.y., jų struktūros kūrimui ir integruotam ivairiu IT priemoniu panaudojimui. Šiame procese naudinga taikyti struktūrinio projektavimo principus, aiškinti, kaip pasirinkti vieną iš alternatyvių struktūros variantų ir kaip realizuoti išskirtus tipinius elementus panaudojant įvairias alternatyvias priemones.

Mokymo medžiaga turi būti paruošta taip, kad studentas galètu ją pasirinkti pagal savo poreikius. Taigi, siūloma įdiegti „,pasirenkamu irankiu krepšelio“ principa. Kadangi didelè dalis studentu mokosi neakivaizdiniu būdu, siūloma sukurti elektroninio mokymosi priemones. Jos ne tik palengvins studijas, bet ir igalins supaprastinti mokomosios medžiagos atnaujinimą. Be to, sudaromos sąlygos automatizuoti ir unifikuoti žiniu kontrolę universitete. Studijų moduliu temos priklauso nuo fakultetu pasirinkimo ir ekspertu nuomonès. KTU Informatikos fakulteto dèstytojai paruošè tokią virtualią informatikos modulių mokymosi priemonę. Studijų medžiaga sudaro paskaitų skaidrès, laboratorinių darbų aprašai, savikontrolès klausimai ir žinių patikrinimo testai. Be to, kiekvienam studijų moduliui paruošta po 4 video paskaitas, kurios skirtos studentamsneakivaizdininkams. Visa medžiaga pateikta virtualioje mokymosi aplinkoje WebCT. 